CONSTANTINE

AND THE CITIES

$\infty$ 
EMPIRE AND AFTER

Series Editor: Clifford Ando

A complete list of books in the series

is available from the publisher. 


\title{
CONSTANTINE AND THE CITIES
}

\author{
$\approx$
}

IMPERIAL AUTHORITY

AND CIVIC POLITICS

NOEL LENSKI

\author{
PENN \\ UNIVERSITY OF PENNSYLVANIA PRESS \\ PHILADELPHIA
}


All rights reserved. Except for brief quotations used for purposes of review or scholarly citation, none of this book may be reproduced in any form by any means without written permission from the publisher.

\author{
Published by \\ University of Pennsylvania Press \\ Philadelphia, Pennsylvania 19104-4112 \\ www.upenn.edu/pennpress
}

Printed in the United States of America on acid-free paper

13579108642

\title{
Library of Congress Cataloging-in-Publication Data \\ Lenski, Noel, author.
}

Constantine and the cities : imperial authority and civic politics / Noel Lenski.

pages : maps ; $\mathrm{cm}$. - (Empire and after)

ISBN 978-0-8122-4777-o (alk. paper)

1. Constantine I, Emperor of Rome, -337. 2. Constantine I, Emperor of Rome, -337Influence. 3. Rome-History-Constantine I, the Great, 306-337. 4. Rome-Politics and government-284-476. 5. Rome-Religion. 6. Power (Social sciences)-RomeHistory. 7. Social change-Rome-History. 8. Christianity and politics-RomeHistory. I. Title. II. Series: Empire and after.

DG315.L46 2016

937'.08-dc23 
For Paul

From whom I have learned much 
This page intentionally left blank 